\title{
Domination and Global Justice YUKSEKDAG Implications of a Social-Republican Account
}

\author{
Fabian Schuppert, Freedom, Recognition and Non-Domination: A \\ Republican Theory of (Global) Justice (Dordrecht: Springer, 2014).
}

The notion of 'freedom as non-domination', with its neo-republican political focus, has been on the rise recently in many ethical debates concerning both territorial and global socio-political questions. We see insightful applications of this very understanding of political freedom which is able to address certain contemporary concerns, interests and reasons at stake for transnational migration, citizenship policies, and democratic procedures. ${ }^{1}$ Nevertheless, extension of this very conception of freedom to the global scope has been a somewhat neglected project, ${ }^{2}$ or to some extent it is deemed unfeasible given the communitarian focus of neorepublican political ideal. In other words, a full-scale neo-republican account of global justice has been a challenging project worth exploring. Schuppert's comprehensive account, Freedom, Recognition and Non-Domination, is an attempt to fill in this gap with an overarching emphasis on 'freedom' as the starting point of his understanding of socio-political justice which presents a social egalitarian neo-republican hybrid with a fundamental interests-based sufficientarianism.

The focal point of concern in Freedom, Recognition and Non-Domination is 'free agency' as in many other liberal accounts. However, what distinguishes Schuppert from the liberal egalitarians as such is his assumption that to be able to have practical freedom, which is the most fundamental good, one should be enjoying a certain socio-normative freedom where the individuals face each other as free and equals. ${ }^{3}$ Schuppert utilizes a Rousseauian concern as such and claims that being free and equal has an important intersubjective social component. On the other hand, his Hegelian reading of agency leads him to the claim that individuals exercise their agency; reason, form, debate and contest their conception of the good not in an isolated manner, but rather within a set

1 For instance, for an insightful application of non-domination to transnational migration, see Sarah Fine, 'Nondomination and the Ethics of Migration', Critical Review of International Social and Political Philosophy 17/1 (2014), 10-30.

2 One exception is Rainer Forst's construction of 'justice as non-domination.' See Rainer Forst, 'A Kantian Republican Conception of Justice as Nondomination', in Andreas Niederberger and Philipp Schink (eds.), Republican Democracy: Liberty, Law and Politics (Edinburgh: Edinburgh University Press, 2013), 154-168.

3 Schuppert (2014), p. 2. 
of 'normative' and 'discursive' social relationships necessary for the exercise of one's agency. ${ }^{4}$

This way, Schuppert introduces the significance of a political system that recognizes the empowering nature of contestation and equal social relations rather than eliminating them. Therefore, to him, justice is only about minimizing the detrimental features of our intersubjective socio-political reality from alienation, ${ }^{5}$ domination, ${ }^{6}$ ossification, ${ }^{7}$ along with exploitation and structural disadvantages as such which ultimately endangers self-realization and selfactualization for individuals. All these are different kinds of threats to our agency, and this is how Schuppert situates his neo-republican concern for nondomination within his understanding of agency.

In relation with his understanding of justice, Schuppert advocates for a teleological social equality account through which social-relational inequalities are unjust to the extent that they are harmful to free socio-normative agency. ${ }^{8}$ To that end, Schuppert presents his institutional framework in which the socio-political institutions 'promote equal social relations and track people's interest fairly and equally in its decision-making processes'. ${ }^{9}$ He discusses the content and justification of the interests as such, in the section titled as Needs, Interests and Rights. He points to the interests relevant to his socio-normative agency, and argue for certain derivative moral rights such as 'right to equal social relations, freedom from domination, alienation, and ossification, as well as a right to political and social voice' ${ }^{10}$

To exemplify his concerns over a bundle of agency-hampering threats, and to point to the necessity of the institutional safeguards, Schuppert refers to how 'work' as a conceptual category or more specifically how 'capitalist wage labour' is structured within contemporary societies. ${ }^{11}$ He claims that the way the concept of work is understood within the contemporary wage labour structure is very much, or even too much, tied to the social standing of individuals, the way an individual is recognized in relation to others, and how contribution, success and self-worth is understood. Schuppert clearly holds the Marxist concern over how capitalist wage labour is detrimental to self-actualization here. Therefore,

4 Schuppert (2014), pp. 8-9.

5 Schuppert states that 'the phenomenon of alienation as an experience of estrangement from one-self, powerlessness, lack of self-confidence and purposelessness is tightly connected to an agent's autonomy', Schuppert (2014), p. 50.

6 It should be noted that Schuppert accommodates Frank Lovett's conceptualization of non-domination that 'domination should be understood as a condition suffered by persons or groups whenever they are dependent on a social relationship in which some other person or group wields arbitrary power over them', Schuppert (2014), p. 29.

7 According to Schuppert, 'ossification is often the underlying reason when it seems extremely difficult in a situation to discern who dominates ... [thus it] ultimately leads to formerly open, discursive and participatory relationships becoming ossified, hegemonic and exclusionary structures', Schuppert (2014), p. 53.

8 Schuppert (2014), pp. 54-57.

9 Schuppert (2014), p. 59.

10 Schuppert (2014), p. 85.

11 Schuppert (2014), p. 112. 


\section{DOMINATION AND GLOBAL JUSTICE IMPLICATIONS OF A SOCIAL-REPUBLICAN ACCOUNT}

he suggests certain institutional practices through which an individual can exist as a socio-normative free agent outside of this economic mode of production without suffering enormous disadvantages, while the education fosters understanding and respect for every individual with different conceptions of the good. Lastly, but most importantly, he also offers a public forum through which this very conceptualization of work can be contested. ${ }^{12}$

On the other hand, in order to make the collective decision-making procedures not detrimental to individual agency, Schuppert offers many institutional features such as accountability, transparency, responsiveness, epistemic reliability, recognition, and respect for interests to sustain that individuals are intersubjectively recognized and treated as free and equal agents without undermining the ultimate normative and political good, freedom. ${ }^{13}$ Regarding individual responsibility, Schuppert keeps his distance from ascribing too much significance to 'choice' as in many responsibility-centric luck egalitarian views. To that end, Schuppert aims at sustaining certain institutional features to strengthen responsibility-endorsement. In other words, he aims at establishing certain mechanisms in order to enable individuals to make free and autonomous choices. ${ }^{14}$

When it comes to the global level, Schuppert argues that there are certain fundamental interest-based rights to be enjoyed by every individual in the globe, while the exclusion and territorialization of rights and powers can persist when it comes to interest-based rights and entitlements which are less-crucial. Regardless, in the end, his sufficientarian global scope is enough for him to argue for a dispersion of power in the international politics in the form 'polycentric and plurarchic decision-making structures' to address global domination arising from monopolization of power within the hands of the state apparatus. ${ }^{15}$ Therefore, Schuppert concludes his insightful and promising account with the prospects of 'global democratic politics of non-domination'. ${ }^{16}$

As Rainer Forst points out, one of the merits of a neo-republican conception of justice as non-domination is situated within its conceptualization of the very understanding of justice itself. ${ }^{17}$ Rather than taking the individuals as simple recipients of certain objectively determined goods, Schuppert also incorporates Philip Pettit's emphasis on discursive control which aims at conceptualizing a free agency with an emphasis on making claims, giving reasons and requiring justifications within a certain socio-political setting. ${ }^{18}$ This way, Schuppert

12 Schuppert (2014), p. 114 .

13 Schuppert (2014), pp. 126-136.

14 Schuppert (2014), p. 48. This is similar to the framework offered by Zofia Stemplowska. See Zofia Stemplowska, 'Making Justice Sensitive to Responsibility', Political Studies 57 (2009), 237-59.

15 Schuppert (2014), p. 171.

16 Schuppert (2014), p. 180.

17 Forst (2013), p. 157.

18 Ian Shapiro, 'On Non-Domination', University of Toronto Law Journal 62 (2012), 293-335. 
goes beyond taking recognition as merely respecting individuals per se, and reconstructs it as a constitutive feature of free agency. In the end, his emphasis on normative social agency is very much interrelated with his understanding of 'freedom-based conception of justice'. However, as Nancy Fraser points out, there is a worry that a mere emphasis on recognition does not necessarily address economic injustices and puts the redistributive concerns to the background. ${ }^{19}$ For that purpose, Fraser aims at a marriage of recognition and redistribution without making one derivative of the other. To me, it seems like Schuppert's fundamental interests-based rights account with a sufficientarian redistribution scheme incorporate Fraser's concern successfully.

The book incorporates many theoretical and political concerns as such embedded in the works of Pettit, Hegel, Marx, Rousseau, Honneth and Nussbaum. The main theoretical contribution of the book is how it eclectically and to some extent successfully unifies many different theoretical tools. This, on the other hand, makes the book a challenging project for the reader. Therefore, for the sake of simplicity, rest of this review will focus on some of the nuances in Schuppert's understanding of freedom and equality, along with global-political implications of his account.

First, I would like to briefly discuss the different components of the theory of freedom Schuppert provides to better understand the theoretical features of the book. To begin with, I should point out that Schuppert does not merely incorporate Pettit's theory of 'freedom as discursive control'. He rather affiliates it with 'freedom as recognition' to ultimately strengthen the idea of non-domination. Interestingly, it is not clear why Schuppert deems 'freedom as discursive' control as necessary component in his theory, while his focus on 'freedom as recognition' might have solely acted as a justification for an account of socio-political justice where free socio-normative agency, non-domination, and alienation are all emphasized as primary political values. ${ }^{20}$ This is one of the examples of how book is consisting of many eclectic questions, justifications, and reconstructions that require a certain background knowledge on each of the notions Schuppert makes use of. As an important side note, this brings us to the question that whether or not a completely non-republican reading of freedom and justice as non-domination is possible.

In the end, one of the worries for philosophical intelligibility is that it is not necessarily clear if such an eclectic defence provides much for the main argument. Regardless, Schuppert's aim is to marry a certain Hegelian conception of free agency with Pettit's political conception of freedom as non-domination

19 Nancy Fraser and Axel Honneth, Redistribution or Recognition: A Political-Philosophical Exchange (London: Verso, 2003).

20 Shapiro makes a similar claim about Pettit's treatment of non-domination as a means to his theory of 'freedom as discursive control'. See Shapiro (2012), p. 310. 


\section{DOMINATION AND GLOBAL JUSTICE IMPLICATIONS OF A SOCIAL-REPUBLICAN ACCOUNT}

to rather strengthen and elucidate the justification for the latter; and to make use of the former in a full scale account of socio-political justice. This, in the end, is in line with main concern of Schuppert. Given that exercising our free agency is only possible within a set of social relationships, the relationship between recognition and non-domination is that the two individuals cannot fully recognize each other as reason-givers and reason-takers while one is being dominated by the other.

Schuppert's understanding of what it means to be equals is the second feature of his book which requires a little more scrutiny. Both in social egalitarian accounts of equality and to some extent within the non-domination reading of freedom, there is an overarching focus on 'structural inequalities'. Depending on one's concern, be it alienation, global power inequalities, power asymmetries within international politics, the emphasis one puts on the content of the structural inequalities as such differ. However, it is hard to understand how one should perceive being 'structurally equal.' Especially, when Schuppert extends the scope of his neo-republican concern to the globe, this issue gains more significance and it requires more scrutiny. What it means to be structurally equal in relation to a member of a different country? Even if one does not provide a comprehensive answer to this question, the political implications of such an argument should seek the ways in which a form of global structural equality is sustained. ${ }^{21}$ This brings us to the questions regarding global-political implications of Schuppert's account.

Long story short, Schuppert is a cosmopolitan. However, his cosmopolitan focus seems as it is not fully reconstructed along with his theoretical underpinnings, but rather presents itself like an afterthought emphasis in the end. He rather thinks that there should be certain international checks and balances so that the rights of individuals shall not be put into jeopardy due to global power relations. ${ }^{22}$ However, what is the generic contribution of an understanding of justice which highlights recognition, non-domination and set of egalitarian social relations? What is the contribution of this work to our understanding of global justice? Does this theory help us problematize power asymmetries and domination in international level in a different way? These questions require elaboration.

Schuppert rather relies mainly on Pogge when he problematizes the global

21 It is understandable that given that equality is an instrumental good for Schuppert, what it means to be structurally equal and questions as such are not comprehensively investigated within the scope of this book. On the other hand, it should be pointed out that Schuppert does not really use the term 'structural inequalities' and rather he refers to the 'social inequalities'. However, Schuppert gets involved with this question in another article. See, Fabian Schuppert, 'Being Equals: Analyzing the Nature of Social Egalitarian Relationships', in Carina Fourie, Fabian Schuppert and Ivo Wallimann-Helmer (eds.), Social Equality: On What It Means to Be Equals (Oxford: Oxford University Press, 2015), 107-128.

22 Schuppert (2014), p. 105. 
structure and power asymmetries. ${ }^{23} \mathrm{I}$ do not think that there is necessarily any issue with such an emphasis, yet Schuppert's socio-normative account actually promises much more than that. Take the example of transnational migration. Schuppert's account actually provides a very illuminating opportunity for the scholars of ethics of migration. It is no surprise that recently there is a rising interest in reading migration-related ethical debates through the lens of neo-republican problematization of domination. However, Schuppert's unique contribution is his emphasis on recognition and how individualsocial-individual relations are the matter of justice. This points to concerns for transnational migration networks, which distribute goods, arrange social settings, create dominating social relations and disperse powers across a variety of agents. This is the focal point of divergence from the conventional liberal statist paradigms in which the territorial sphere is perceived as the locus of rights, opportunities, goods and all the other metrics of justice. An appeal to domination, on the other hand, has a methodological advantage to map the moral issues relevant to contemporary transnational migration regime as it enables us to start a ground-up analysis through seeking and casting light upon the actual instances of domination. And more importantly it is an insightful prism to contest how the international borders regime affects aspirations and agency and how transnational migration networks distribute opportunities and goods. ${ }^{24}$

One of the most striking and promising features of this insightful work is its emphasis on non-domination and non-alienation as integral components of free agency within the scope of a very comprehensive global justice account. The second promising feature of this work is how it starts its reasoning by focusing on injustices as well. It is important to refer to Frank Lovett on this regard, and how pointing to negative-value-laden judgments are cognitively easier for individuals. ${ }^{25}$ All in all, the book offers many metaphysical and political questions within the context of a promising global justice debate.

YusufYuksekdag

Centre for Applied Ethics

Linköping University

Email:yusufyuksekdag@liu.se

\section{the global justicenetwork}

23 Schuppert (2014), pp. 170-171.

24 Hein De Haas, H, 'Migration Theory: Quo Vadis?’ Working Papers, Determinants of International Migration (2014); Nina Glick Schiller, 'A Global Perspective on Transnational Migration: Theorizing Migration without Methodological Nationalism', in Rainer Bauböck and Thomas Faist (eds.), Diaspora and Transnationalism: Concepts, Theories and Methods (Amsterdam: Amsterdam University Press, 2010), 109-129.

25 Frank Lovett, A General Theory of Domination and Justice (Oxford: Oxford University Press, 2010). 